\title{
Comparison of oral and intravenous tranexamic acid in total hip arthroplasty: a systematic review and meta-analysis
}

\author{
Yiming Qi $i^{1,2,3,4,5}$, Yingjuan $\mathrm{Li}^{2,6}$, Chen Wang ${ }^{1,2,3,4,5}$, Hui Chen ${ }^{1,2,3,4,5}$ and Yunfeng Rui ${ }^{1,2,3,4,5^{*}}$ (D)
}

\begin{abstract}
Background: Total hip arthroplasty is associated with substantial blood loss which can lead to postoperative anemia. The purpose of this systematic review and meta-analysis was to compare efficacy and safety of oral tranexamic acid (TXA) and intravenous TXA.

Methods: PubMed, EMBASE, and Cochrane Library were searched from inception until December 2019. A combined searching strategy of subject words and random words was adopted. Only clinical randomized controlled trials were included. The comparisons were made with regard to total blood loss, hemoglobin drop, transfusion rate, and postoperative thromboembolic complications including deep vein thrombolism (DVT) and pulmonary embolism (PE). The meta-analysis was conducted by using the Review Manager 5.3, and bias evaluation was performed based on the Cochrane Handbook 5.1.0.
\end{abstract}

Results: In this meta-analysis, five randomized controlled trials were included. The results showed that there were no significant differences between the oral TXA group and intravenous TXA group concerning total blood loss [mean difference $(\mathrm{MD})=3.01,95 \%$ confidence interval $(95 \% \mathrm{Cl}):-43.90$ to $49.92, p=0.90$ ], hemoglobin drop $(\mathrm{MD}=$ $0.05,95 \% \mathrm{Cl}:-0.10$ to $0.20, p=0.50$ ) and transfusion rate of allogeneic blood [risk ratio (RR) $=1.09,95 \%$ Cl: 0.46 to $2.62, p=0.84]$. No significant difference was found in the incidence of thromboembolic events (RR $=1.71,95 \% \mathrm{Cl}$ : 0.71 to $4.16, p=0.97)$.

Conclusions: Compared with intravenous TXA, oral TXA is equally able to reduce total blood loss, hemoglobin drop, and transfusion requirement for total hip arthroplasty. It is a lower-cost method that does not increase the incidence of thromboembolic events.

Keywords: Tranexamic acid, Oral, Intravenous, Total hip arthroplasty, Meta-analysis, Blood loss

\section{Background}

Total hip arthroplasty (THA) has been demonstrated to be an effective surgical alternative for patients with endstage hip diseases [1]. More than 500,000 THAs are performed each year in the UK and USA [2].

\footnotetext{
* Correspondence: ruiyunfeng@126.com

'Department of Orthopaedics, Zhongda Hospital, School of Medicine,

Southeast University, No. 87 Ding Jia Qiao, Nanjing, Jiangsu 210009, PR China

${ }^{2}$ Multidisciplinary Team (MDT) for Geriatric Hip Fracture Comprehensive Management, Zhongda Hospital, School of Medicine, Southeast University, No. 87 Ding Jia Qiao, Nanjing, Jiangsu 210009, PR China

Full list of author information is available at the end of the article
}

THA is associated with substantial blood loss which can lead to postoperative anemia [3-6]. Kim et al [4] reported that in the THA procedure, the blood loss ranged between 1000 and $2000 \mathrm{ml}$, and this increased the requirement of allogeneic blood transfusion. However, allogeneic blood transfusion might increase the risk of adverse effects, such as viral infection, immune response, cardiovascular dysfunction, added cost and even death [7-13]. Recently, the enhanced recovery after surgery protocol has been improved in THA, and the key to the improvement is the blood management [14-16]. A variety of methods have been used to reduce blood loss, including controlled

(c) The Author(s). 2020 Open Access This article is licensed under a Creative Commons Attribution 4.0 International License, which permits use, sharing, adaptation, distribution and reproduction in any medium or format, as long as you give

appropriate credit to the original author(s) and the source, provide a link to the Creative Commons licence, and indicate if changes were made. The images or other third party material in this article are included in the article's Creative Commons licence, unless indicated otherwise in a credit line to the material. If material is not included in the article's Creative Commons licence and your intended use is not permitted by statutory regulation or exceeds the permitted use, you will need to obtain permission directly from the copyright holder. To view a copy of this licence, visit http://creativecommons.org/licenses/by/4.0/. 
hypotension, regional anaesthesia, autologous blood transfusion, intra-operative blood salvage, and the administration of erythropoietin and antifibrinolytic agents $[17,18]$.

THA may cause hyperfibrinolysis that may last up to $18 \mathrm{~h}$ postoperatively [19]. Lee et al. [18] reported that hyperfibrinolysis may account for $60 \%$ of total blood loss. Therefore, attention should be paid to perioperative application of antifibrinolytics. Antifibrinolytics include Tranexamic acid (TXA), aprotinin and $\varepsilon$ aminocaproic acid, etc.
TXA is a synthetic lysine analog that works by binding to plasminogen and blocking the interaction of plasminogen with fibrin, thereby inhibiting fibrinolysis [20, 21]. This mechanism helps reduce blood loss, but theoretically may also put the patient at an increased risk for thromboembolic events [22]. Recently, multiple studies showed that intravenous TXA during perioperation could effectively reduce blood loss without increasing the risk for thromboembolic events. However, the relevant studies on oral modules

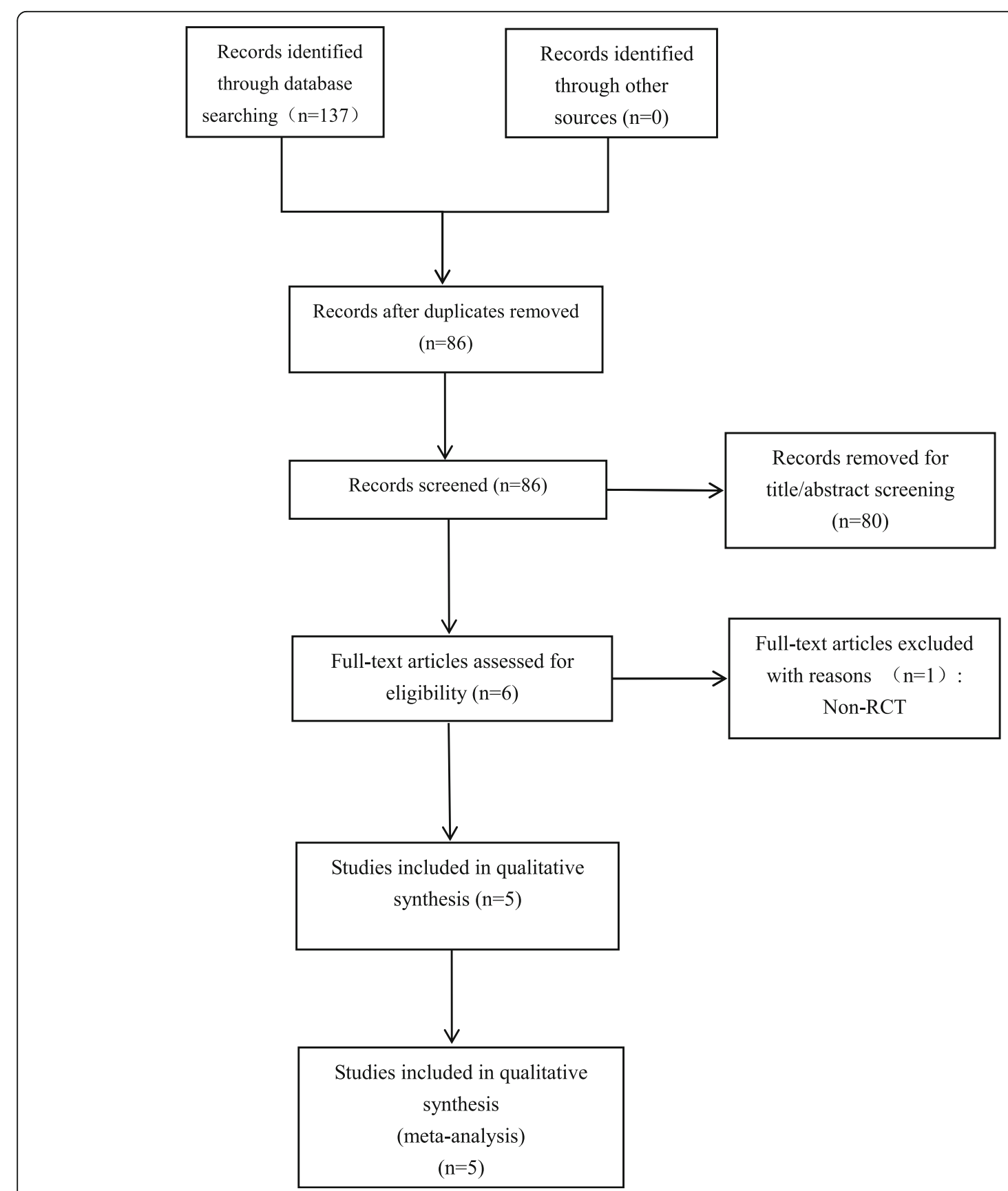

Fig. 1 Preferred reporting items for systematic reviews and meta-analyses 
are not sufficient, leading to a disagreement over its efficacy and safety.

The purpose of this systemic review and meta-analysis was to verify the efficacy and safety of oral TXA. Our hypothesis was that oral TXA might be as effective and safe as intravenous TXA in patients who undergo THA.

\section{Materials and methods}

\section{Search strategy}

Two reviewers (Yiming Qi and Yingjuan Li) searched PubMed, EMBASE, and Cochrane Library respectively from inception until December 2019. A combined searching strategy of subject words and random words was adopted. The key words, including "THR", "Arthroplasty, Replacement, Hip", "THA", "total hip replacement", "total hip arthroplasty" and "tranexamic acid" were used in combination. The concrete searching strategy for PubMed was as follows: $((((((T H R))$ OR "Arthroplasty, Replacement, Hip"[Mesh]) OR THA) OR total hip replacement) OR total hip arthroplasty) AND tranexamic acid) AND oral). We included randomized controlled trials (RCTs) that compared oral TXA with intravenous TXA for reducing blood loss or transfusion in patients who underwent THA. Reference lists of all eligible studies and relevant reviews were manually searched for additional studies.

\section{Eligibility criteria}

\section{Inclusion criteria were as follows:}

1) Patients: adult patients who underwent THA.

2) Intervention: perioperative application of oral or intravenous TXA.

3) Comparison: comparing oral TXA with intravenous TXA.

4) Outcomes: the outcomes concerning efficacy included total blood loss, hemoglobin drop, and transfusion rate; the rate of thromboembolic complications including deep vein thrombosis and pulmonary embolism was chosen as the outcome concerning safety. Total blood loss was selected as the primary outcome.

5) Type of studies: only clinical RCTs were included.

\section{Exclusion criteria were as follows}

1) Patients: underage patients or adult patients who underwent revision THA or bilateral THA.

2) Intervention: topical administration of TXA.

3) Comparison: no comparison was made between oral TXA and intravenous TXA.

4) Outcomes: total blood loss was not included as an outcome.

5) Type of studies: non-RCTs or concrete description unsuitable for data extraction; basic or laboratory RCTs; letters and comments.

\section{Data extraction}

Two authors (Yiming Qi and Yingjuan Li) independently used the aforementioned search strategy to select the articles from the databases. The titles and abstracts of the articles were reviewed separately. When there was a doubt, the full-text was retrieved for further scrutiny. The included studies were examined thoroughly and independently by two authors (Yiming Qi and Yingjuan $\mathrm{Li}$ ), and the key data were extracted. Disagreement was resolved by comparing notes or consulting a senior reviewer. The data extracted included author name, country, publish year, sample size, mean age, number of female patients, TXA intervention, prophylactic use of antithrombotics, transfusion criteria and outcome data.

\section{Quality of included studies}

Two reviewers (Yiming Qi and Yingjuan Li) independently assessed the risk of bias of every RCT according to the rules of Cochrane Handbook 5.1.0. We created a 'risk of bias' table containing the following 7 items: random sequence generation, allocation concealment,

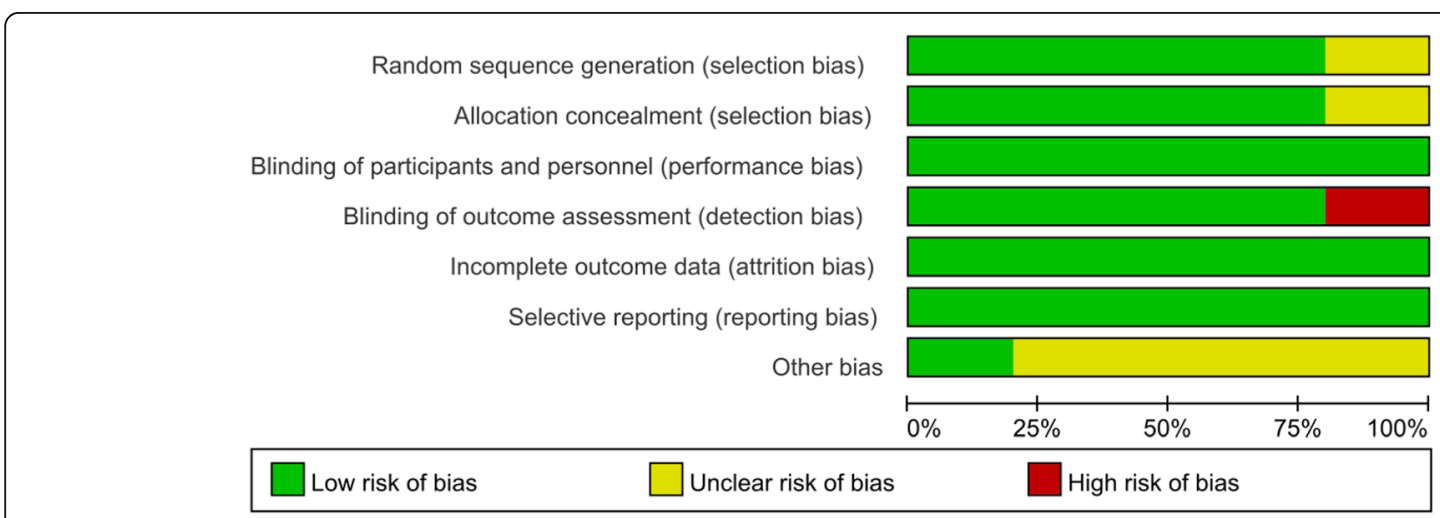

Fig. 2 Risk of bias graph 
blinding, incomplete outcome data, free of selective reporting and other bias. All the items were described as "low risk of bias," "unclear risk of bias," or "high risk of bias."

\section{Statistical analysis}

Meta-analysis was conducted by using the Review Manager 5.3 software pakage (The Cochrane Collaboration, Oxford, UK). For dichotomous data, the risk ratio (RR) with 95\% confidence interval (95\% CI) was calculated (the transfusion rate and the occurrence of thromboembolic events), and for continuous variables (total blood loss, hemoglobin drop) the mean differences
(MDs) were calculated. Statistical heterogeneity was assessed with the $p$ and $\mathrm{I}^{2}$ values using the standard Chisquare test. $\mathrm{I}^{2}>50 \%$ or $p<0.1$ indicated a significant heterogeneity and a random-effects model was applied for the meta-analysis. Otherwise, a fixed-effects model was used.

\section{Results}

\section{Search results}

A total of 137 studies were identified from the search of the databases and none of them came from other sources. Eighty-six studies remained after the duplicates were removed. Then, we scanned the titles and the abstracts of

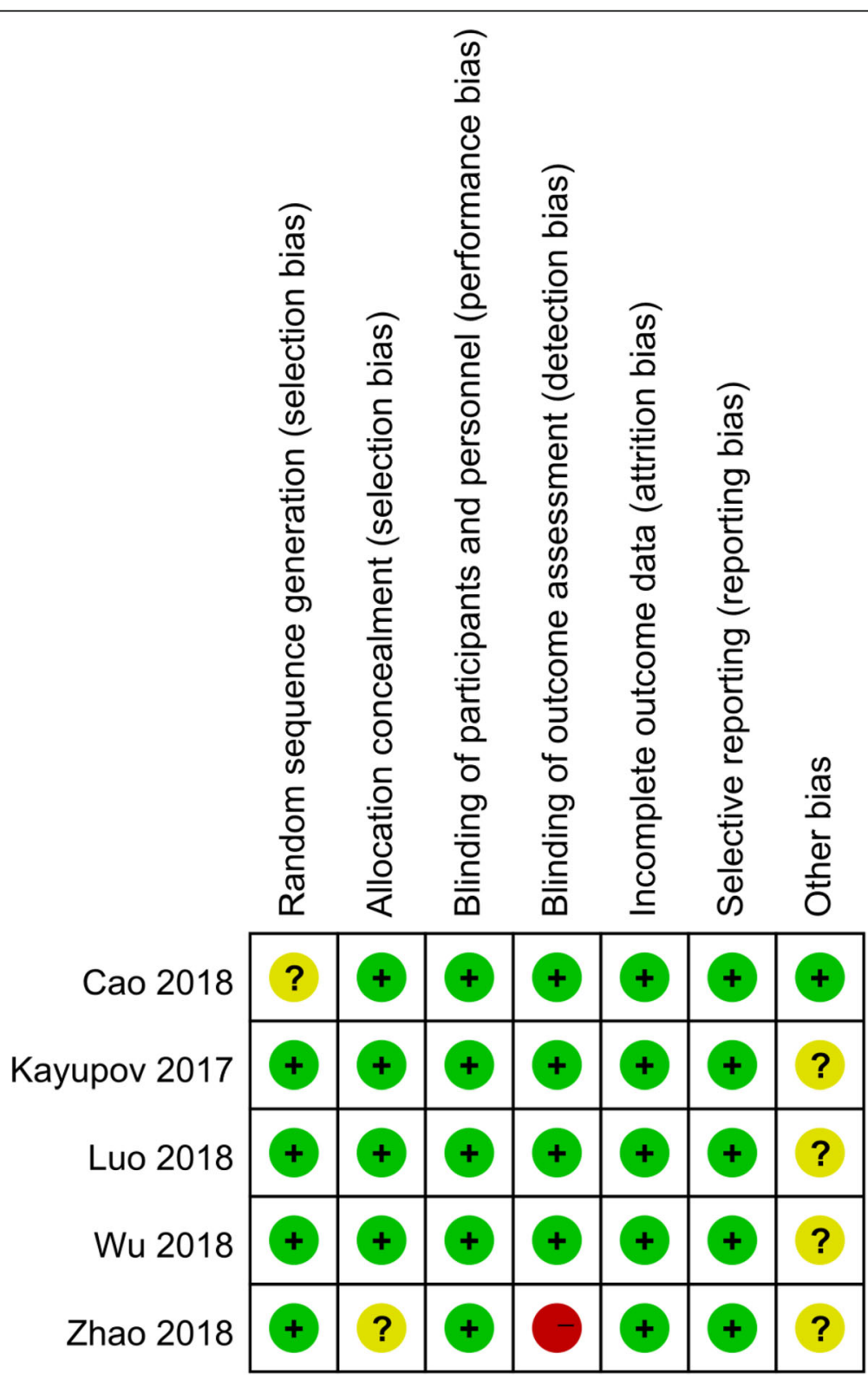

Fig. 3 Risk of bias summary 


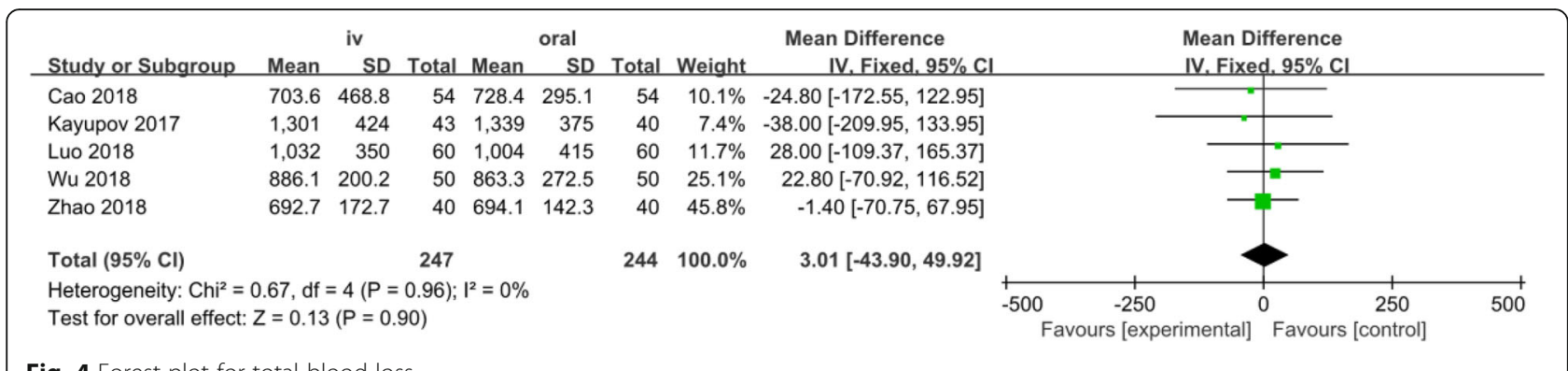

Fig. 4 Forest plot for total blood loss

the 86 citations according to the inclusion and exclusion criteria. As a consequence, 80 citations were excluded. Next, the six remaining studies were carefully full-textreviewed. Finally five RCTs [23-27] were included in the meta-analysis (Fig. 1).

\section{Quality of the included studies}

Risk of bias in the included studies is shown in Figs. 2 and 3. For every bias item, the risk is presented as the percentage across all included studies, which indicates the proportion of different levels of risk of bias for each item. Among the included studies, three studies were randomized by computer-generated numbers [25-27], one by random number technique [24], and the remaining one did not report the method of random sequence generation [23]. Four studies conducted the concealment with sealed, opaque envelope [23-26]. Doubleblinding was reported in all the five included studies [23-27]. In four studies the outcome assessors were blinded [23-26], and in the remaining one [27], the data analyst was not blinded.

\section{General characteristics of included studies}

All included studies were RCTs published between 2017 and 2018. Four studies were conducted in China and one in the USA. The sample size of the groups ranged from 40 to 60 and the average age of every group varied between 55 to 67.6 years old. As to transfusion indications, in all the studies, transfusion was given when the level of hemoglobin was $<70 \mathrm{~g} / \mathrm{L}$ or $70-100 \mathrm{~g} / \mathrm{L}$ with accompanying symptoms of anemia. For deep vein thrombosis prophylaxis, low molecular weight heparin was used in hospital, and in the four Chinese researches, Rivaroxaban was administered after the patients were discharged. Three studies adopted multiple doses [23, 26, 27], and in the other two studies a single dose was applied to every patient $[24,25]$ (Table 1).

Table 1 General characteristics of included studies

\begin{tabular}{|c|c|c|c|c|c|c|c|c|c|}
\hline $\begin{array}{l}\text { Study } \\
\text { (Country) }\end{array}$ & Year & $\begin{array}{l}\text { Study } \\
\text { type }\end{array}$ & $\begin{array}{l}\text { Sample } \\
\text { size O/l }\end{array}$ & $\begin{array}{l}\text { Mean } \\
\text { age } \\
\text { O/l }\end{array}$ & $\begin{array}{l}\text { Female } \\
\text { patients } \\
\text { O/I }\end{array}$ & Oral group intervention & $\begin{array}{l}\text { Intravenous group } \\
\text { intervention }\end{array}$ & $\begin{array}{l}\text { Prophylactic } \\
\text { antithrombotic }\end{array}$ & Transfusion trigger \\
\hline $\begin{array}{l}\text { Cao } \\
\text { (China) } \\
{[23]}\end{array}$ & 2018 & $\mathrm{RCT}$ & $54 / 54$ & $\begin{array}{l}55.7 / \\
55.7\end{array}$ & $31 / 34$ & $\begin{array}{l}2 \mathrm{~g} \text { of oral TXA } 2 \mathrm{~h} \\
\text { before surgery and } 4 \mathrm{~h} \text {, } \\
10 \mathrm{~h}, 16 \mathrm{~h} \text { after surgery }\end{array}$ & $\begin{array}{l}2 \mathrm{~g} \text { TXA } 5-10 \mathrm{~min} \text { be- } \\
\text { fore surgery and } 6 \mathrm{~h} \text {, } \\
12 \mathrm{~h}, 18 \mathrm{~h} \text { after surgery }\end{array}$ & $\begin{array}{l}\text { LMWH in } \\
\text { hospital } \\
\text { Rivaroxaban after } \\
\text { discharge }\end{array}$ & $\begin{array}{l}\text { Hb level was }<70 \mathrm{~g} / \mathrm{L} \\
\text { or } 70-100 \mathrm{~g} / \mathrm{L} \text { with } \\
\text { symptoms of anemia }\end{array}$ \\
\hline $\begin{array}{l}\text { Kayupov } \\
\text { (America) } \\
{[24]}\end{array}$ & 2017 & $\mathrm{RCT}$ & $40 / 43$ & $60 / 55$ & $20 / 21$ & $\begin{array}{l}1.95 \mathrm{~g} \text { TXA } 2 \mathrm{~h} \text { before } \\
\text { surgery }\end{array}$ & $1 \mathrm{~g}$ TXA before surgery & Warfarin & $\begin{array}{l}\text { Hb level was }<70 \mathrm{~g} / \mathrm{L} \\
\text { or } 70-100 \mathrm{~g} / \mathrm{L} \text { with } \\
\text { symptoms of anemia }\end{array}$ \\
\hline $\begin{array}{l}\text { Luo } \\
\text { (China) } \\
{[25]}\end{array}$ & 2018 & $\mathrm{RCT}$ & $60 / 60$ & $\begin{array}{l}67.6 / \\
67.0\end{array}$ & $32 / 33$ & $\begin{array}{l}2 \mathrm{~g} \text { TXA } 2 \mathrm{~h} \text { before } \\
\text { surgery }\end{array}$ & $\begin{array}{l}20 \mathrm{mg} / \mathrm{kg} \text { TXA } 5 \mathrm{~min} \\
\text { before surgery }\end{array}$ & $\begin{array}{l}\text { Clexane in } \\
\text { hospital } \\
\text { Rivaroxaban after } \\
\text { discharge }\end{array}$ & $\begin{array}{l}\mathrm{Hb} \text { level was }<70 \mathrm{~g} / \mathrm{L} \\
\text { or } 70-100 \mathrm{~g} / \mathrm{L} \text { with } \\
\text { symptoms of anemia }\end{array}$ \\
\hline $\begin{array}{l}\text { Zhao } \\
\text { (China) } \\
{[27]}\end{array}$ & 2018 & $\mathrm{RCT}$ & $40 / 40$ & $\begin{array}{l}60.1 / \\
59.5\end{array}$ & 18/17 & $\begin{array}{l}20 \mathrm{mg} / \mathrm{kg} 2 \mathrm{~h} \text { before } \\
\text { surgery and } 3 \mathrm{~h} \text { after } \\
\text { surgery }\end{array}$ & $\begin{array}{l}15 \mathrm{mg} / \mathrm{kg} \text { TXA } 10 \mathrm{~min} \\
\text { before surgery and } 3 \mathrm{~h} \\
\text { after surgery }\end{array}$ & $\begin{array}{l}\text { Clexane in } \\
\text { hospital } \\
\text { Rivaroxaban after } \\
\text { discharge }\end{array}$ & $\begin{array}{l}\mathrm{Hb} \text { level was }<70 \mathrm{~g} / \mathrm{L} \\
\text { or } 70-100 \mathrm{~g} / \mathrm{L} \text { with } \\
\text { symptoms of anemia }\end{array}$ \\
\hline $\begin{array}{l}\text { Wu } \\
\text { (China) } \\
{[26]}\end{array}$ & 2018 & $\mathrm{RCT}$ & $50 / 50$ & $\begin{array}{l}66.5 / \\
65.1\end{array}$ & $21 / 20$ & $\begin{array}{l}2 \mathrm{~g} \text { of oral TXA } 2 \mathrm{~h} \\
\text { before surgery and } 3 \mathrm{~h} \text {, } \\
6 \mathrm{~h} \text { after surgery }\end{array}$ & $\begin{array}{l}2 \mathrm{~g} \text { TXA } 10 \mathrm{~min} \text { before } \\
\text { surgery and } 3 \mathrm{~h}, 6 \mathrm{~h} \\
\text { after surgery }\end{array}$ & $\begin{array}{l}\text { Clexane in } \\
\text { hospital } \\
\text { Rivaroxaban after } \\
\text { discharge }\end{array}$ & $\begin{array}{l}\text { Hb level was }<70 \mathrm{~g} / \mathrm{L} \\
\text { or } 70-100 \mathrm{~g} / \mathrm{L} \text { with } \\
\text { symptoms of anemia }\end{array}$ \\
\hline
\end{tabular}




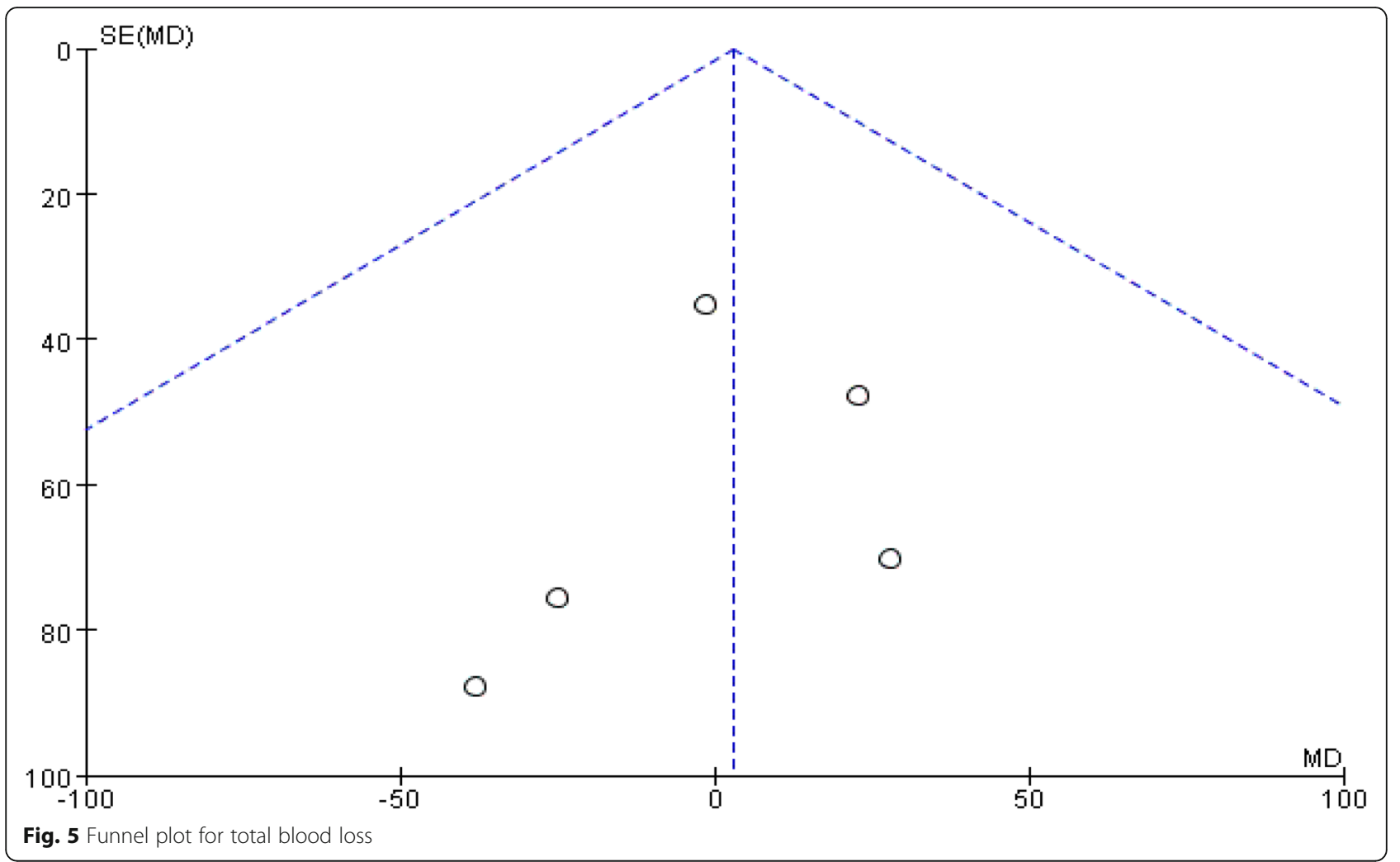

\section{Outcomes for meta-analysis Total blood loss}

Five studies involving 491 patients reported the total blood loss. A fixed-effects model was applied because no significant heterogeneity was found among these studies $\left(p=0.96, \mathrm{I}^{2}=0 \%\right)$. No significant difference was detected in the total blood loss between the two groups $(\mathrm{MD}=$ 3.01, 95\% CI: -43.90 to 49.92, $p=0.90$, Fig. 4). Funnel plot for total blood loss was employed to evaluate publication bias. The funnel plot shows little asymmetry which suggests little publication bias for the metaanalysis of total blood loss (Fig. 5).

\section{Hemoglobin drop}

Five studies involving 491 patients reported the postoperation hemoglobin drop. A fixed-effects model was applied because no significant heterogeneity was found among these studies $\left(p=0.66, \mathrm{I}^{2}=0 \%\right)$. No significant difference was detected in the total blood loss between the two groups ( $\mathrm{MD}=0.05,95 \% \mathrm{CI}$ : -0.10 to $0.20, p=0.50$, Fig. 6 ).

\section{Transfusion rate}

Four studies involving 383 patients reported the transfusion rate. A fixed-effects model was applied because no significant heterogeneity was found among these studies $\left(p=0.62, \mathrm{I}^{2}=0 \%\right)$. No significant difference was detected in the transfusion rate between the two groups $(\mathrm{RR}=$ 1.09, $95 \%$ CI: 0.46 to $2.62, p=0.84$, Fig. 7 ).

\section{Thromboembolic events}

Two studies involving 188 patients reported the incidence of thromboembolic events. A fixed-effects model

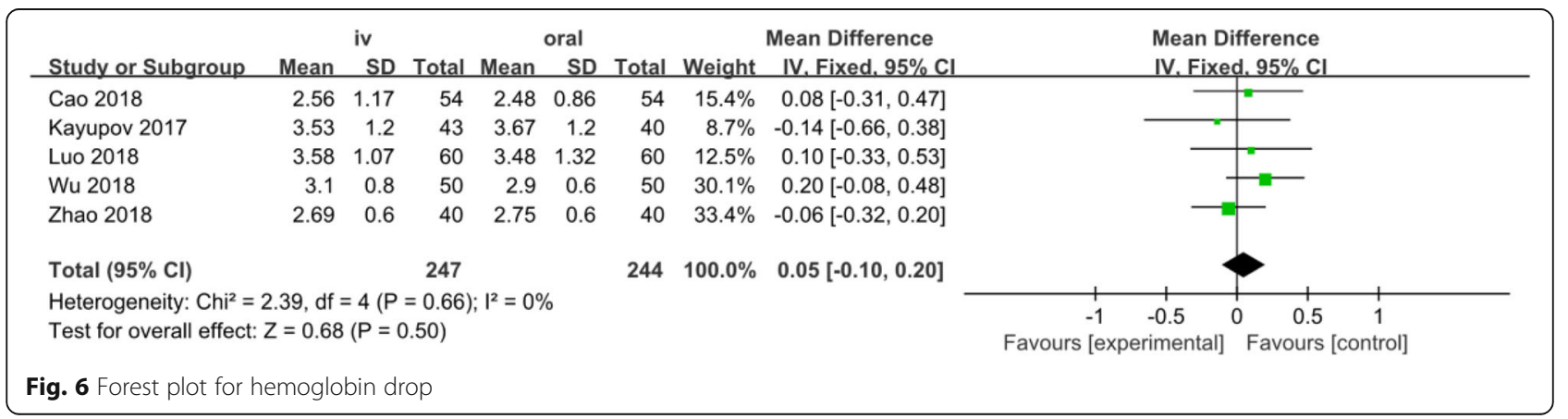




\begin{tabular}{|c|c|c|c|c|c|c|c|c|c|}
\hline Study or Subgroup & $\begin{array}{r}\text { iv } \\
\text { Events }\end{array}$ & Total & $\begin{array}{c}\text { oral } \\
\text { Events }\end{array}$ & Total & Weight & $\begin{array}{l}\text { Risk Ratio } \\
\text { M-H. Fixed. } 95 \% \mathrm{Cl}\end{array}$ & $\begin{array}{r}\text { Risk R } \\
\text { M-H. Fixec }\end{array}$ & $\begin{array}{l}\text { Ratio } \\
\text { d. } 95 \% \mathrm{Cl}\end{array}$ & \\
\hline Kayupov 2017 & 1 & 43 & 3 & 40 & $34.1 \%$ & $0.31[0.03,2.86]$ & $=$ & & \\
\hline Luo 2018 & 5 & 60 & 4 & 60 & $43.9 \%$ & $1.25[0.35,4.43]$ & & & \\
\hline Wu 2018 & 2 & 50 & 1 & 50 & $11.0 \%$ & $2.00[0.19,21.36]$ & & & \\
\hline Zhao 2018 & 2 & 40 & 1 & 40 & $11.0 \%$ & $2.00[0.19,21.18]$ & & & \\
\hline Total $(95 \% \mathrm{Cl})$ & & 193 & & 190 & $100.0 \%$ & $1.09[0.46,2.62]$ & & & \\
\hline Total events & 10 & & 9 & & & & & & \\
\hline \multicolumn{7}{|c|}{$\begin{array}{l}\text { Heterogeneity: } \mathrm{Chi}^{2}=1.78, \mathrm{df}=3(P=0.62) ;\left.\right|^{2}=0 \% \\
\text { Test for overall effect: } Z=0.20(P=0.84)\end{array}$} & $\begin{array}{lll}0.01 & 0.1 & 1 \\
& \text { Favours [experimental] }\end{array}$ & $\begin{array}{c}10 \\
\text { Favours [control] }\end{array}$ & 100 \\
\hline
\end{tabular}

Fig. 7 Forest plot for transfusion rate

was applied because no significant heterogeneity was found among these studies $\left(p=0.66, \mathrm{I}^{2}=0 \%\right)$. No significant difference was detected in the incidence of thromboembolic events between the two groups $(\mathrm{RR}=$ 1.71, $95 \%$ CI: 0.71 to $4.16, p=0.23$, Fig. 8 ).

\section{Sensitivity analysis and subgroup analysis}

No significant heterogeneity was observed in "total blood loss", "hemoglobin drop", "transfusion rate", and "incidence of thromboembolic events". We excluded one single study to evaluate the influence of the deleted study to the overall result. As a result, omission of any one single study didn't significantly alter the results, indicating that the results were statistically stable and reliable. No subgroup analysis was conducted for the heterogeneity was low and the number of included studies was small.

\section{Discussion}

Blood loss during and after THA ranged from 700 to 2000 $\mathrm{mL}$, which led to 16 to $37 \%$ of the patients requiring transfusions $[4,28,29]$. We found both oral and intravenous TXA yielded similar results in terms of the amount of total blood loss, transfusion rate, and hemoglobin drop. This result is in accordance with a former meta-analysis based on five RCTs about arthroplasties [30]. Evangelista et al [31] reported an elevated risk of deep vein thrombosis and pulmonary embolism after application of TXA. However, several meta-analyses showed TXA might not increase thromboembolic events in patients undergoing THA and the incidence of thromboembolic events was very low [30, 32-35]. Lucas-Polomeni et al [36] reported drug allergy with anaphylactic shock after intravenous TXA. Klak et al [37] reported that topical TXA carried the theoretical risk of periprosthetic infection caused by needle contamination that might even aggravate sepsis. Therefore, the oral form of TXA is considerably safer. Sabbag et al [38] found that, even for patients with a history of VTE, the risk of recurrent VTE (2\%) after contemporary THA and TKA was low, and the rate did not increase with the use of intravenous TXA. Besides, we noticed that the patients included in this metaanalysis underwent THA for end-stage hip diseases, such as osteoarthritis, osteonecrosis of the femoral head and developmental dysplasia of hip. Nonetheless, nowadays more and more geriatric patients are suffering from hip fractures, for some of them it may be better to receive THA [39]. Qi et al [40] demonstrated that intravenous TXA reduced total blood loss and transfusion requirements, but did not increase the incidence of thromboembolic events in patients who suffered from hip fractures and underwent THA .

Although Tranexamic acid was discovered more than 50 years ago, the clinical utilization of tranexamic to reduce blood loss and transfusion requirements became popular in the past decade. It was even not included in the 350 essential medicines by the WHO until 2013 [41]. The optimal route, dosage and time for TXA administration in THA remain controversial. In the pooled studies, a loading dose in combination with a following dose or following doses was adopted in three studies [23, $26,27]$, and a single bolus dose was administered in two

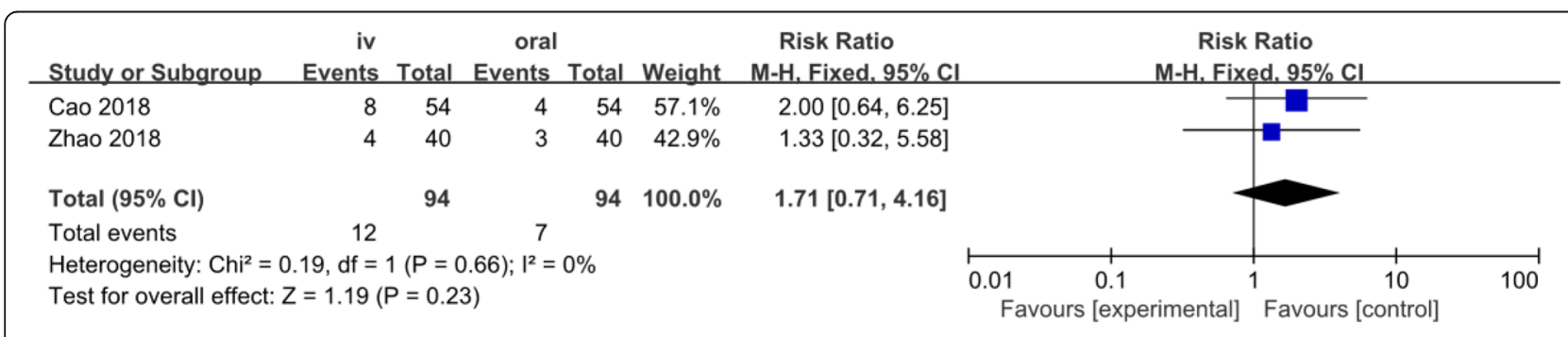

Fig. 8 Forest plot for the incidence of thromboembolic events 
studies [24, 25]. In the two single-dose studies, the average blood loss were more than $1000 \mathrm{ml}$ in intravenous and oral TXA groups, and was more substantial than that in the other three studies. Pilbrant et al [42] reported that the bioavailability of oral TXA was only $34 \%$ of the same dose of intravenous TXA. In addition, blood TXA was completely eliminated within $8 \mathrm{~h}$. TXA reached a peak 2 to $3 \mathrm{~h}$ after oral administration, and the peak plasma level appeared immediately after intravenous administration. The half-life of equipotential doses for the two forms were similar. A TXA plasma concentration of 5 to $10 \mathrm{mg} / \mathrm{L}$ has been shown to effectively inhibit fibrinolysis and is considered therapeutic. For oral TXA, it takes approximately $2 \mathrm{~h}$ at a dose of $2 \mathrm{~g}$ to reach a therapeutic concentration and the level is maintained for approximately $6 \mathrm{~h}$ [42]. Some studies showed that hyperfibrinolysis lasted 18 to $24 \mathrm{~h}$ postoperatively [43, 44]. Therefore, repeated application of TXA for another 18 to $24 \mathrm{~h}$ could further inhibit fibrinolysis, thereby further reducing blood loss. Some studies showed that multiple boluses of oral or IV TXA postoperatively were effective and safe [22, 45-47].

Compared with non-pharmacologic hemostatic agents and even with another pharmacological antifibrinolytic (epsilon-aminocaproic acid), TXA is the most costeffective medicine to minimize perioperative blood loss in THA [31, 48, 49]. Zhao et al [27] showed that the cost of blood transfusion was much lower with oral TXA (US\$ 137 total patients) than with intravenous TXA (US\$ 273 total patients) or without application of TXA (US\$ 1230 total patients). Cao et al [23] found that, compared with intravenous TXA, oral TXA saved US\$ 39 per patient during hospitalization. Wu et al [26] reported that the cost of oral TXA (US\$ 88 per patient) was significantly lower than that of intravenous TXA (US\$ 463 per patient).

Our met-analysis had several strengths. First, this meta-analysis, comparing oral and intravenous TXA solely in THA, included the latest published RCTs. Second, this meta-analysis was methodologically of high quality since it was conducted in strict accordance with the guidelines of the Cochrane Handbook.

Our study had some limitations. First, only five RCTs were included, and the sample size was small. Second, four out of five studies were conducted in the same setting in China. Third, no subgroup analysis was conducted due to a small number of studies. Larger-sample and high-quality RCTs involving different countries and races are warranted for further verification of the efficacy and safety of oral TXA.

\section{Conclusions}

Compared with intravenous TXA, oral TXA is equally capable of reducing total blood loss, hemoglobin drop, and transfusion requirement for THA. It is a lower-cost alternative that does not increase the risk for thromboembolic events.

\section{Abbreviations}

95\% Cl: 95\% confidence interval; DVT: Deep vein thrombolism; LMWH: Low molecular weight heparin; MD: Mean difference; PE: Pulmonary embolism; RCT: Randomized controlled trial; RR: Risk ratio; THA: Total hip arthroplasty; TXA: Tranexamic acid

\section{Acknowledgements}

Not applicable.

\section{Authors' contributions}

YMQ contributed to the study design, performed all data collection and analysis, and wrote the manuscript. YJL, CW and $\mathrm{HC}$ participated in the searching of databases, the selection of the included studies and the data analysis. YFR contributed to the study design, data interpretation, and manuscript revision. All authors have read and approved the final manuscript.

\section{Funding}

This work was supported by "Summit of the Six Top Talents" Program of Jiangsu Province (2013-WSW-054); Jiangsu Provincial Medical Talent, The Project of Invigorating Health Care through Science, Technology and Education (ZDRCA2016083); Soft Science Research Projects of Nanjing Science and Technology Commission (2016ZD014); The Six Projects Sponsoring Talent Summits of Jiangsu Province, China (LGY2017099).

\section{Availability of data and materials}

Please contact the authors for relevant data.

Ethics approval and consent to participate

Not applicable.

\section{Consent for publication}

Not applicable.

\section{Competing interests}

The authors declare that they have no competing interests.

\section{Author details}

${ }^{1}$ Department of Orthopaedics, Zhongda Hospital, School of Medicine, Southeast University, No. 87 Ding Jia Qiao, Nanjing, Jiangsu 210009, PR China. ${ }^{2}$ Multidisciplinary Team (MDT) for Geriatric Hip Fracture

Comprehensive Management, Zhongda Hospital, School of Medicine, Southeast University, No. 87 Ding Jia Qiao, Nanjing, Jiangsu 210009, PR China. ${ }^{3}$ Orthopaedic Trauma Institute, Southeast University, No. 87 Ding Jia Qiao, Nanjing, Jiangsu 210009, PR China. ${ }^{4}$ Trauma Center, Zhongda Hospital, School of Medicine, Southeast University, No. 87 Ding Jia Qiao, Nanjing, Jiangsu 210009, PR China. ${ }^{5}$ School of Medicine, Southeast University, No. 87 Ding Jia Qiao, Nanjing, Jiangsu 210009, PR China. 'Department of Geriatrics, Zhongda Hospital, School of Medicine, Southeast University, No. 87 Ding Jia Qiao, Nanjing, Jiangsu 210009, PR China.

Received: 22 December 2019 Accepted: 20 February 2020 Published online: 08 April 2020

\section{References}

1. Jolback P, Rolfson O, Mohaddes M, Nemes S, Karrholm J, Garellick G, et al. Does surgeon experience affect patient-reported outcomes 1 year after primary total hip arthroplasty? Acta Orthop. 2018;89:265-71.

2. $\quad$ Pivec R, Johnson AJ, Mears SC, Mont MA. Hip arthroplasty. Lancet. 2012;380: 1768-77.

3. Bierbaum BE, Callaghan JJ, Galante JO, Rubash HE, Tooms RE, Welch RB. An analysis of blood management in patients having a total hip or knee arthroplasty. J Bone Joint Surg Am. 1999:81:2-10.

4. Kim C, Park SS, Davey JR. Tranexamic acid for the prevention and management of orthopedic surgical hemorrhage: current evidence. J Blood Med. 2015;6:239-44. 
5. Saleh A, Small T, Chandran PA, Schiltz NK, Klika AK, Barsoum WK. Allogenic blood transfusion following total hip arthroplasty: results from the nationwide inpatient sample, 2000 to 2009. J Bone Joint Surg Am. 2014;96: e155.

6. Wong $\mathrm{S}$, Tang $\mathrm{H}$, de Steiger $\mathrm{R}$. Blood management in total hip replacement: an analysis of factors associated with allogenic blood transfusion. ANZ J Surg. 2015;85:461-5.

7. Appassakij H, Promwong C, Rujirojindakul P, Wutthanarungsan R, Silpapojakul K. The risk of blood transfusion-associated Chikungunya fever during the 2009 epidemic in Songkhla Province, Thailand. Transfusion. 2014; 54:1945-52.

8. Bilgili MG, Ercin E, Peker G, Kural C, Basaran SH, Duramaz A, et al. Efficiency and cost analysis of cell saver auto transfusion system in total knee arthroplasty. Balkan Med J. 2014;31:149-53.

9. Dan M, Liu D, Martos SM, Beller E. Intra-operative blood salvage in total hip and knee arthroplasty. J Orthop Surg (Hong Kong). 2016;24:204-8.

10. Huang F, Wu D, Ma G, Yin Z, Wang Q. The use of tranexamic acid to reduce blood loss and transfusion in major orthopedic surgery: a meta-analysis. J Surg Res. 2014;186:318-27.

11. Izuel RM, Garcia EJ, Gomez-Barrera M, Cuenca EJ, Abad SR, Rabanaque HM Relationship between allogeneic blood transfusion, iron deficiency and nosocomial infection in patients with hip fracture. Med Clin (Barc). 2008;131: 647-52.

12. Marik PE, Corwin HL. Efficacy of red blood cell transfusion in the critically ill: a systematic review of the literature. Crit Care Med. 2008;36:2667-74.

13. Zhang H, Chen J, Chen F, Que W. The effect of tranexamic acid on blood loss and use of blood products in total knee arthroplasty: a meta-analysis. Knee Surg Sports Traumatol Arthrosc. 2012;20:1742-52.

14. Klapwijk LC, Mathijssen NM, Van Egmond JC, Verbeek BM, Vehmeijer SB. The first 6 weeks of recovery after primary total hip arthroplasty with fast track. Acta Orthop. 2017:88:140-4.

15. Malek IA, Royce G, Bhatti SU, Whittaker JP, Phillips SP, Wilson IR, et al. A comparison between the direct anterior and posterior approaches for tota hip arthroplasty: the role of an 'enhanced recovery' pathway. Bone Joint J. 2016;98-B:754-60.

16. Stowers MD, Manuopangai L, Hill AG, Gray JR, Coleman B, Munro JT. Enhanced recovery after surgery in elective hip and knee arthroplasty reduces length of hospital stay. ANZ J Surg. 2016:86:475-9.

17. Cardone D, Klein AA. Perioperative blood conservation. Eur J Anaesthesiol. 2009:26:722-9.

18. Lee QJ, Chang WY, Wong YC. Blood-sparing efficacy of oral tranexamic acid in primary total hip arthroplasty. J Arthroplast. 2017;32:139-42.

19. Eriksson Bl, Hultman E, Martinell S, Eriksson E, Tengborn L, Risberg B. Regional fibrinolysis following total hip replacement. Thromb Res. 1991;62: 441-7.

20. Aguilera-Roig X, Jordan-Sales M, Natera-Cisneros L, Monllau-Garcia JC, Martinez-Zapata MJ. Tranexamic acid in orthopedic surgery. Rev Esp Cir Ortop Traumatol. 2014;58:52-6.

21. Dunn CJ, Goa KL. Tranexamic acid: a review of its use in surgery and other indications. Drugs. 1999;57:1005-32

22. Alipour M, Tabari M, Keramati M, Zarmehri AM, Makhmalbaf H. Effectiveness of oral tranexamic acid administration on blood loss after knee artroplasty: a randomized clinical trial. Transfus Apher Sci. 2013:49:574-7.

23. Cao G, Huang Z, Xie J, Huang Q, Xu B, Zhang S, et al. The effect of oral versus intravenous tranexamic acid in reducing blood loss after primary total hip arthroplasty: a randomized clinical trial. Thromb Res. 2018;164:4853

24. Kayupov E, Fillingham YA, Okroj K, Plummer DR, Moric M, Gerlinger TL, et al. Oral and intravenous Tranexamic acid are equivalent at reducing blood loss following total hip arthroplasty: a randomized controlled trial. J Bone Joint Surg Am. 2017;99:373-8.

25. Luo ZY, Wang HY, Wang D, Zhou K, Pei FX, Zhou ZK. Oral vs intravenous vs topical tranexamic acid in primary hip arthroplasty: a prospective, randomized, double-blind, controlled study. J Arthroplasty. 2018;33:786-93.

26. Wu Y, Zeng Y, Hu Q, Li M, Bao X, Zhong J, et al. Blood loss and costeffectiveness of oral vs intravenous tranexamic acid in primary total hip arthroplasty: a randomized clinical trial. Thromb Res. 2018;171:143-8.

27. Zhao H, Xiang M, Xia Y, Shi X, Pei FX, Kang P. Efficacy of oral tranexamic acid on blood loss in primary total hip arthroplasty using a direct anterior approach: a prospective randomized controlled trial. Int Orthop. 2018;42: 2535-42.
28. Kim JL, Park JH, Han SB, Cho IY, Jang KM. Allogeneic blood transfusion is a significant risk factor for surgical-site infection following total hip and knee arthroplasty: a meta-analysis. J Arthroplast. 2017;32:320-5.

29. Toy PT, Kaplan EB, McVay PA, Lee SJ, Strauss RG, Stehling LC. Blood loss and replacement in total hip arthroplasty: a multicenter study. The preoperative autologous blood donation study group. Transfusion. 1992;32:63-7.

30. Li GL, Li YM. Oral tranexamic acid can reduce blood loss after total knee and hip arthroplasty: a meta-analysis. Int J Surg. 2017;46:27-36.

31. Evangelista PJ, Aversano MW, Koli E, Hutzler L, Inneh I, Bosco J, et al. Effect of tranexamic acid on transfusion rates following total joint arthroplasty: a cost and comparative effectiveness analysis. Orthop Clin North Am. 2017:48: 109-15.

32. Gandhi R, Evans HM, Mahomed SR, Mahomed NN. Tranexamic acid and the reduction of blood loss in total knee and hip arthroplasty: a meta-analysis. BMC Res Notes. 2013:6:184

33. Li G, Zhang Y, Teng J. Efficiency and safety of oral tranexamic acid in total joint arthroplasty: a meta-analysis of randomized controlled trial. Int J Surg. 2017:47:148-50.

34. Luo W, Sun RX, Jiang H, Ma XL. The efficacy and safety of topical administration of tranexamic acid in spine surgery: a meta-analysis. J Orthop Surg Res. 2018;13:96

35. Chen S, Wu K, Kong G, Feng W, Deng Z, Wang H. The efficacy of topical tranexamic acid in total hip arthroplasty: a meta-analysis. BMC Musculoskelet Disord. 2016:17:81

36. Lucas-Polomeni MM, Delaval Y, Menestret P, Delaval P, Ecoffey C. A case of anaphylactic shock with tranexamique acid (Exacyl). Ann Fr Anesth Reanim. 2004:23:607-9.

37. Klak M, Anakkala N, Wang W, Lange S, Jonsson IM, Tarkowski A, et al. Tranexamic acid, an inhibitor of plasminogen activation, aggravates staphylococcal septic arthritis and sepsis. Scand J Infect Dis. 2010;42:351-8.

38. Sabbag OD, Abdel MP, Amundson AW, Larson DR, Pagnano MW. Tranexamic acid was safe in arthroplasty patients with a history of venous thromboembolism: a matched outcome study. J Arthroplast. 2017:32:\$246-50.

39. Gullberg B, Johnell O, Kanis JA. World-wide projections for hip fracture. Osteoporos Int 1997:7:407-13.

40. Qi Y, Wang H, Li Y, Ma B, Xie T, Wang C, et al. The efficacy and safety of intravenous tranexamic acid in hip fracture surgery: a systematic review and meta-analysis. J Orthop Translat. 2019;19:1-11.

41. World Health Organization (WHO) (2017) WHO model list of essential medicines. Available at http://www.who.int/medicines/publications/ essentialmedicines/en/.

42. Pilbrant A, Schannong M, Vessman J. Pharmacokinetics and bioavailability of tranexamic acid. Eur J Clin Pharmacol. 1981;20:65-72.

43. Blanie A, Bellamy L, Rhayem Y, Flaujac C, Samama CM, Fontenay M, et al. Duration of postoperative fibrinolysis after total hip or knee replacement: a laboratory follow-up study. Thromb Res. 2013;131:e6-11.

44. Sharrock NE, Go G, Harpel PC, Ranawat CS, Sculco TP, Salvati EA. The John Charnley Award. Thrombogenesis during total hip arthroplasty. Clin Orthop Relat Res. 1995;319:16-27.

45. Zohar E, Ellis M, Ifrach N, Stern A, Sapir O, Fredman B. The postoperative blood-sparing efficacy of oral versus intravenous tranexamic acid after total knee replacement. Anesth Analg. 2004;99:1679-83.

46. Xie J, Ma J, Yao H, Yue C, Pei F. Multiple boluses of intravenous tranexamic acid to reduce hidden blood loss after primary total knee arthroplasty without tourniquet: a randomized clinical trial. J Arthroplast. 2016;31:245864

47. Xie J, Hu Q, Ma J, Huang Q, Pei F. Multiple boluses of intravenous tranexamic acid to reduce hidden blood loss and the inflammatory response following enhanced-recovery primary total hip arthroplasty: a randomised clinical trial. Bone Joint J. 2017;99-B:1442-9.

48. Lin ZX, Woolf SK. Safety, efficacy, and cost-effectiveness of tranexamic acid in orthopedic surgery. Orthopedics. 2016;39:119-30.

49. Ramkumar DB, Ramkumar N, Tapp SJ, Moschetti WE. Pharmacologic hemostatic agents in total joint arthroplasty-a cost-effectiveness analysis. J Arthroplast. 2018;33:2092-9.

\section{Publisher's Note}

Springer Nature remains neutral with regard to jurisdictional claims in published maps and institutional affiliations. 